\title{
СИНТЕЗ И ИССЛЕДОВАНИЕ ПРОТИВООПУХОЛЕВОЙ АКТИВНОСТИ ПОЛИАКРИЛАТОВ ЗОЛОТА (III)
}

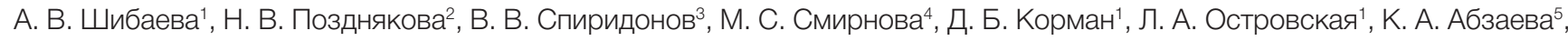
А. В. Белякова ${ }^{1,6}$, Ю. К. Бирюкова ${ }^{1,6}$, М. В. Зылькова, К. П. Иванов ${ }^{7}$ А. Б. Шевелев ${ }^{4}$, В. А. Кузьмин ${ }^{1}$

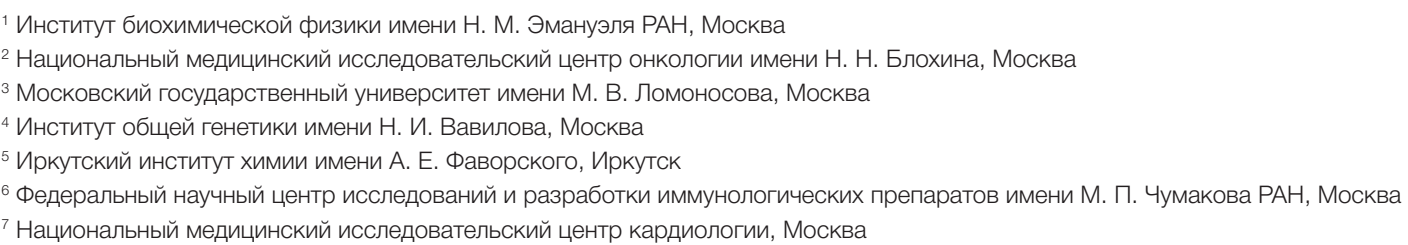

Национальный медицинский исследовательский центр кардиологии, Москва

Аурумакрил проявляет гемостатическую активность и обладает онколитическим и онкостатическим действием в отношении перевиваемых карцином in vivo. Образцы аурумакрила, полученные по известной методике, недостаточно стандартизированы по растворимости, что не позволяет изучить механизмы реакции и цитостатического действия. Целью работы было исследовать влияние на свойства аурумакрила следующих параметров проведения реакции его синтеза: молекулярная масса полиакрилатного полимера (в диапазоне 2-1000 кДа), наличие в качестве противоиона $\mathrm{H}^{+}$ или $\mathrm{Na}^{+}$, соотношение иона тетрахлораурата и звена полиакрилатного полимера (1: 5 или 1: 10), общая концентрация полиакрилатного полимера в момент синтеза (0,1 или 3\%), а также влияние лиофильного высушивания аурумакрила. Сопоставление цитотоксической активности полученных образцов аурумакрила со значительно различающимся соотношением ионов золота и полиакрилатного полимера в отношении клеток карциномы молочной железы человека MCF-7 позволило установить, что удельное содержание в препарате полиакрилатного полимера и его молекулярная масса практически не сказываются на биологических свойствах конечного продукта. Методом УФ-спектроскопии показано влияние концентрации ионов Аu (III) в аурумакриле на их цитотоксическую активность.

Ключевые слова: аурумакрил, полиакрилат, золотохлористоводородная кислота, тетрахлораурат, протовоопухолевое средство, цитотоксическая активность, MCF-7

Финансирование: исследование поддержано Министерством образования и науки Российской Федерации (Соглашения о представлении субсидии № 14.607.21.0199 от 26.09.2017, уникальный идентификатор RFMEFI60717Х0199). Спектроскопические измерения проведены на базе ЦКП «Новые материалы и технологии" ИБХФ РАН.

$\triangle$ Для корреспонденции: Алексей Борисович Шевелев ул. Губкина, д. 3, г. Москва, 119991; shevel_a@hotmail.com

Статья получена: 28.09.2018 Статья принята к печати: 26.10.2018

DOI: $10.24075 /$ vrgmu.2018.071

\section{SYNTHESIS OF AU (III) POLYACRYLATES AND STUDY OF THEIR TUMORICIDAL ACTIVITY}

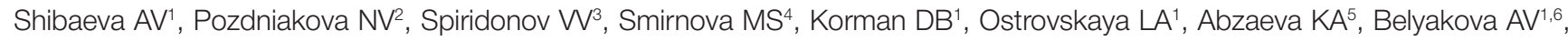
Biryukova YuK ${ }^{1,6}$, Zylkova MV ${ }^{1}$, Ivanov $\mathrm{KP}^{7}$, Shevelev $\mathrm{AB}^{4}{ }^{\square}, \mathrm{Kuzmin} V \mathrm{~A}^{1}$

${ }^{1}$ Emanuel Institute of Biochemical Physics, Moscow

2 Blokhin Russian Cancer Research Centre, Moscow

${ }^{3}$ Lomonosov Moscow State University, Moscow

${ }^{4}$ Vavilov Institute of General Genetics, Russian Academy of Sciences, Moscow

${ }^{5}$ Favorsky Irkutsk Institute of Chemistry, Irkutsk

${ }^{6}$ Chumakov Federal Scientific Center for Research and Development of Immune-and- Biological Products, Russian Academy of Sciences, Moscow

${ }^{7}$ National Medical Research Center of Cardiology, Moscow

Aurumacryl is an incomplete metal salt of poly(acrylic acid) that exhibits hemostatic activity and inhibits the growth of transplantable carcinomas in vivo. The samples of aurumacryl synthesized following the original technique are insufficiently soluble, which complicates the study of the mechanisms involved in their synthesis and underlying their cytotoxic effect. The aim of this work was to study the impact of the following factors on aurumacryl properties: the molecular weight of the polyacrylate polymer in a range between 2 and $1,000 \mathrm{kDa}$, the presence of a counterion $\mathrm{H}^{+}$or $\mathrm{Na}^{+}$, the molar ratio of $\mathrm{AuCl}_{4}^{-}$ to the polyacrylate polymer $(1: 5$ and $1: 10)$, the total concentration of the polyacrylate polymer during synthesis $(0.1$ and $3 \%$ ), and the type of drying (lyophilization). By comparing the cytotoxicity of aurumacryl samples with significantly different molar ratio of gold ions to the polyacrylate polymer against human breast carcinoma cells (MCF-7), we established that the proportion of the polymer and its molecular weight in the sample do not affect the biological properties of the synthesized substance. Using UV spectroscopy, we revealed that the concentration of Au (III) ions in aurumacryl determines its cytotoxicity.

Keywords: aurumacryl, polyacrylate, chloroauric acid tetrahydrate, antitumor therapy, cytotoxicity, MCF-7

Funding: the study was supported by the Ministry of Science and Higher Education of the Russian Federation (Subsidy Contract 14.607.21.0199 dated 26.09.2017 Project ID RFMEFI60717X0199). Spectroscopy was performed at the Shared Research Facility of Favorsky Irkutsk Institute of Chemistry, RAS.

$\triangle$ Correspondence should be addressed: Alexei B. Shevelev

Gubkina 3, Moscow, 119991; shevel_a@hotmail.com

Received: 28.09.2018 Accepted: 26.10.2018

DOI: 10.24075/brsmu.2018.071 
Субстанция аурумакрил, впервые описанная рядом авторов [1], представляет собой неполную металлическую соль полиакриловой кислоты (ПАК), содержащей ионы золота (III). На основании норм расхода исходных реагентов в этих публикациях сделан вывод, что массовая доля металла в субстанции составляет 8,03 мас.\%, а молекулярная масса полимера колеблется в пределах 100-300 кДа. Субстанция охарактеризована формулой:

$$
\left(-\mathrm{CH}_{2}-\mathrm{CHCOOH}-\right)_{n}\left(-\mathrm{CH}_{2} \mathrm{CHCOOAuCl}{ }_{3} \mathrm{H}-\right)_{m},
$$

где $n=1263 ; m=124$.

Описанный способ получения субстанции аурумакрила основан на взаимодействии водных растворов ПАК и золотохлористоводородной кислоты $\left(\mathrm{HAuCl}_{4}\right)$ при комнатной температуре [1]. В раствор ПАК с $\mathrm{M}_{r}=100000$ и концентрацией 5,7\% добавляют $\mathrm{HAuCl}_{4}$ в пропорции, соответствующей 8,3\% теоретического содержания золота в составе неполной золотой соли полиакриловой кислоты. Реакционную смесь перемешивают, полученный раствор высушивают в вакуумном эксикаторе. Субстанция представляет собой плотную пленку желтого цвета. Физико-химические характеристики аурумакрила, синтезированного по описанному способу, представлены ИК-спектрами Фурье, содержащими характеристические полосы поглощения для карбоксильной и карбоксилатной групп при 1720 и 1570 см $^{-1}$ соответственно. Эти данные не позволяют оценить фактическое содержание в аурумакриле основных компонентов: полиакриловой кислоты, ионов золота (III), ионов золота (I), металлического золота, других анионов и катионов.

Целью работы было усовершенствовать способ синтеза аурумакрила, обеспечивающего получение стандартного и устойчивого по химическому составу образца с достаточной растворимостью в физиологическом растворе (воде), а также разработать физико-химический способ оценки качества аурумакрила, позволяющего предсказывать его биологическую активность. С этой целью для получения композитов были использованы коммерчески доступные полимеры ПАК и полиакрилат натрия (ПА-Na) с охарактеризованными массами. В ходе синтеза комплексов ПАК соотношение аниона $\mathrm{AuCl}_{4}$ и звена ПАК составляло $1: 5$ или 1: 10.

В отличие от метода, описанного ранее, в настоящей работе исходную ПАК подвергали тщательному обессоливанию с помощью проточного диализа в течение нескольких суток, по окончании синтеза растворы полученных золото-полимерных препаратов подвергали высушиванию не на воздухе, а с помощью лиофильной сушки, для чего растворы аурумакрила замораживали в жидком азоте и вакуумировали.

Результат синтеза оценивали по растворимости образцов, по содержанию в них золота в солевой форме при помощи УФ-спектроскопии, по цитотоксической активности на клетках MCF-7 и по содержанию металлического золота в форме наночастиц методом трансмиссионной электронной микроскопии.

\section{МАТЕРИАЛЫ И МЕТОДЫ}

\section{Реактивы}

В качестве исходных реагентов для синтеза использовали коммерческие препараты ПАК и ПА-Na (SigmaAldrich; CША) со степенями полимеризации (среднее число звеньев на молекулу) 23, 80, 160, 1 389, 1944,3472 и 13 889. Средняя степень полимеризации и ее дисперсия охарактеризована производителем. В качестве второго основного компонента использовали безводную золотохлористоводородную кислоту (ОАО «Аурат»; Москва) с содержанием золота 48\%.

\section{Подготовка полиакрилатных полимеров к синтезу}

Для выполнения синтеза использовали образцы ПАК со средними молекулярными массами 1633 Да, 11360 Да, 100000 Да, 140000 Да, 250000 Да, 1000000 Да, указанными производителем, а также исходные препараты полиакрилата натрия (SigmaAldrich; США) со средними молекулярными массами 2100 Да, 15000 Да, 132350 Да, 185370 Да, 330980 Да, 1324000 Да.

Все исходные препараты ПАК до использования в синтезе подвергали дополнительной очистке методом проточного диализа в течение нескольких суток, а затем тщательно высушивали с использованием лиосильной сушки.

Для получения золотосодержащих комплексов ПАК использовали растворы полимеров 0,1\% вес. и 3\% вес. Для этого навески полимеров массой 50 мг растворяли в 50 мл воды и 1,67 мл воды соответственно. Растворение полимеров проводили в течение 12 ч при комнатной температуре при непрерывном перемешивании на магнитной мешалке.

\section{Синтез аурумакрила}

Добавление золотохлористоводородной кислоты к растворам предварительно деионизированных полимеров осуществляли следующим образом:

- к 0,1\% вес. растворам ПАК по каплям добавили 50 мкл водного раствора, содержащего 23,8 мг и 47,6 мг золотохлористоводородной кислоты;

- к 3\% вес. растворам ПАК по каплям добавили 30 мкл водного раствора, содержащего 23,8 мг и 47,6 мг золотохлористоводородной кислоты;

- к 0,1\% вес. растворам полиакрилата натрия по каплям добавили 50 мкл водного раствора, содержащего 18,4 мг и 36,7 мг золотохлористоводородной кислоты;

- к 3\% вес. растворам ПАК по каплям добавили 30 мкл водного раствора, содержащего 18,4 мг и 36,7 мг золотохлористоводородной кислоты.

Реакцию вели в течение 24 ч при комнатной температуре при непрерывном перемешивании на магнитной мешалке со скоростью 60 об./мин.

Полученные образцы очищали от низкомолекулярных компонентов методом проточного диализа. С этой целью использовали диализные мешки MWCO 15 000. Растворы золотосодержащих полимерных препаратов (1,7-20 мл) помещали в диализные мешки и диализовали против воды в течение 3 ч при комнатной температуре.

По окончании диализа полученные растворы замораживали при $-70{ }^{\circ} \mathrm{C}$, после чего подвергали лиосильному высушиванию. Ряд препаратов не подвергали высушиванию, а хранили при $+4{ }^{\circ} \mathrm{C}$ с соблюдением правил асептики.

\section{Определение растворимости образцов аурумакрила}

Для каждого из сухих образцов определяли примерную растворимость в воде, последовательно добавляя аликвоты воды по 100 мкл к навеске массой 1 мг и наблюдая за 
растворением вещества в течение 30 мин при комнатной температуре. В случае, если вещество не растворялось, к суспензии добавляли дополнительную аликвоту воды, повторяя процедуру до полного растворения.

\section{Оценка содержания ионной формы золота в концентрированных растворах аурумакрила}

Определение содержания золота в ионной форме в модифицированных производных проводили при $\lambda=226,5$ нм в 100 мM НСl. Для этого аликвоту 10 мкл концентрированного раствора, полученного при определении растворимости сухих образцов, или раствора, полученного непосредственно после синтеза без высушивания, вносили в раствор 100 мМ HCl объемом 3 мл и определяли величину оптической плотности $\mathrm{A}_{226.5}$. Для каждого образца определяли выход золота в солевой форме по окончании синтеза, для чего вычисляли величину A226,5 ( $\left.\approx \mathrm{HAuCl}_{4}\right]$, мкM) относительно содержания общих сухих веществ образца в концентрированном растворе (без учета содержания остаточной влаги в сухом препарате). Для проведения экспериментов на клетках концентрации всех образцов выравнивали по поглощению при $\lambda=226,5$.

Исследование цитотоксической активности образцов аурумакрила на клеточной линии MCF-7 с помощью МТT-теста

В лунки 96-луночного культурального планшета Costar вносили по 5000 клеток и культивировали в среде DMEM (Панэко; Россия) с 10\% эмбриональной телячьей сывороткой В течение 24 ч при $37^{\circ} \mathrm{C}$ и содержании 5\% CO (180 мкл на лунку). В среду объемом 180 мкл, находящуюся в каждой лунке, добавляли образец аурумакрила (предварительно концентрации образцов выравнивали по поглощению при $\lambda=226,5)$, растворенный в воде объемом 20 мкл на лунку, и продолжали инкубацию при $37^{\circ} \mathrm{C}$ и содержании 5\% $\mathrm{CO}_{2}$ в течение 24 ч. В каждую лунку добавляли 10 мкЛ МТТ-реагента (3-(4,5-диметилтиазол-2-ил)-2,5дифенилтетразолиумбромид) до концентрации 0,5 мг/мл (номер в каталоге SigmaAldrich 57360-69-7), инкубировали в течение 3 ч и определяли A570 с помощью планшетного спектрофотометра Multiskan Go (Thermo Fisher Scientific; США).

\section{Исследование содержания наночастиц} металлического золота в образцах аурумакрила с помощью трансмиссионной электронной микроскопии

Аликвоту водного раствора аурумакрила объемом 3 мкл, содержащего 1-5 мкг золотосодержащего полимера, наносили на медную сетку плотностью 200 mesh (SPI Supplies; CША) диаметром 3,5 мм, высушивали на воздухе в течение 5 мин, после чего вакуумировали. Анализ выполняли на установке JEM-100B (JEOL; Япония), оснащенной приставкой для рентгенофазового анализа, при ускоряющем напряжении 120 кВ.

Анализ полученного изображения частиц, обнаруженных в поле микроскопа, проводили с помощью программы анализа изображения ImageJ (некоммерческий свободно доступный продукт National Institutes of Health; США), в которой определяли площадь каждого темного пятна с учетом увеличения (масштаба). Анализировали не менее 10 случайно выбранных полей для каждого образца. Определив линейные размеры частиц и их количество, с помощью программы Excel для Windows вычисляли долю частиц, попадающих в каждый из пяти диапазонов диаметра: 1-10, 11-20, 20-50, 50-100 и >100 нм.

\section{РЕЗУЛЬТАТЫ ИССЛЕДОВАНИЯ}

В результате синтеза была создана линейка из 23 образцов аурумакрила, полученных из ПАК и полиакрилата натрия различных молекулярных масс с соотношением аниона AuCl-4 и звена ПАК как 1: 5 или 1: 10 при концентрации исходного полимера в реакционной смеси 3\% или 0,1\%.

Препараты, подвергавшиеся лиофильной сушке (10 образцов), были перерастворены в воде и продемонстрировали хорошую растворимость.

Известно, что золотохлористоводородная кислота в водных растворах при нейтральном и щелочном $\mathrm{pH}$ подвергается постепенному гидролизу с высвобождением соляной кислоты и увеличению кислотности среды [2]. При кислых значениях $\mathrm{pH}(<1)$ эта реакция невозможна. При исследовании водного раствора золотохлористоводородной кислоты в $100 \mathrm{mM} \mathrm{HCl} \mathrm{было}$ установлено наличие выраженного максимума при $\lambda=226,5$ нм, причем коэфрфициент экстинкции $\varepsilon$ составил $3,5 \times 10^{4}$ л•моль ${ }^{-1} \cdot \mathrm{cM}^{-1}$. Эта величина хорошо согласуется с литературными данными [2]. Коэффициент экстинкции полиакрилатов находился в диапазоне до $10^{6}$ л•моль ${ }^{-1} \cdot \mathrm{CM}^{-1}$. Наночастицы золота при $\lambda=226,5$ нм не показывали поглощения, за исключением эффректов светорассеяния. Поэтому определение содержания золота в ионной форме в модифицированных производных проводили при $\lambda=226,5$ нм в 100 мM HCl (см. Материалы и методы).

С целью проверки гипотезы о том, что цитотоксическая активность аурумакрила определяется содержанием Au (III), все исследуемые образцы аурумакрила, синтезированные в ходе данной работы, и контрольный образец, полученный по ранее описанному способу (образец № 1), были приведены в форму растворов с одинаковым содержанием $\mathrm{Au}$ (III), определяемого по поглощению при $\lambda=226,5$ нм. Эти растворы были исследованы на цитотоксическую активность при одинаковых концентрациях, равных 9,1 мЕд/мл ( $\mathrm{IC}_{50}$ контрольного образца) и 91,0 мЕд/мл (10-кратное превышение $I_{50}$ контрольного образца). Результаты определения, усредненные по трем независимым определениям, представлены в табл. 1.

Несмотря на существенно различающееся содержание ионного Au (мкмоль/мг), удельная активность всех образцов после выравнивания их концентрации по содержанию ионов Au оказывается одинаковой и совпадает с таковой для контрольного образца аурумакрила, полученного по ранее описанному способу. Биологическая активность образцов аурумакрила после выравнивания $A_{226,5}$ в стоковых растворах совпадает как при концентрации, соответствующей $\mathrm{IC}_{50}$ контрольного образца, так и при концентрации, 10-кратно превышающей $I_{50}$. Это наблюдение доказывает, что действующим началом аурумакрила, обеспечивающим его цитотоксичность in vitro, являются ионы Au. Функция полиакрилатного полимера, по-видимому, заключается в экранировании этих ионов от различных органических молекул, способных восстановить их, переведя в неактивную форму металлических наночастиц.

Для подтверждения предположения о том, что снижение выхода золота в ионной форме при синтезе образцов аурумакрила обусловлено его спонтанным восстановлением и переходом в форму металлических 
наночастиц, часть образцов аурумакрила, синтезированных в рамках настоящей работы, исследовали методом трансмиссионной электронной микроскопии (ТЭМ) (табл. 2).

По мере увеличения молекулярной массы полимера, используемого для синтеза аурумакрила, неуклонно возрастает доля наночастиц золота, имеющих размеры $>10$ нм. Такие частицы являются агрегатами наночастиц меньшего размера (< 10 нм). Вне зависимости от молекулярной массы ПАК, доля агрегированных наночастиц по сравнению с мономерными резко возрастает при уменьшении соотношения Au (III) к звену полиакрилата с $1: 5$ до $1: 10$. Использование для синтеза полиакрилата в форме $\mathrm{Na}^{+}$-соли приводит, во-первых, к значительному увеличению среднего размера наночастиц, во-вторых, к гораздо более выраженной агрегации наночастиц золота. Так, в образцах, полученных на основе полиакрилатов натрия со степенями полимеризации 3472 и 13889 при соотношении ионов золота и звена полиакрилата $1: 10$, численная доля наночастиц золота размером 100 нм составила 75\%. В других образцах на основе ПА-Na такие

Таблица 1. Условия синтеза, физико-химические и биологические свойства образцов аурумакрила

\begin{tabular}{|c|c|c|c|c|c|c|c|c|c|}
\hline \multirow{2}{*}{$\begin{array}{l}\text { № } \\
\text { обр. }\end{array}$} & \multirow{2}{*}{$\begin{array}{c}\text { Концентрация } \\
\text { исходного } \\
\text { полимера } \\
\text { при синтезе, } \\
\text { мас.\% }\end{array}$} & \multirow{2}{*}{$\begin{array}{c}\text { Мr исходного } \\
\text { полимера, } \\
\text { кДа }\end{array}$} & \multirow{2}{*}{$\begin{array}{c}\text { Противо- } \\
\text { ион }\end{array}$} & \multirow{2}{*}{$\begin{array}{c}\text { Соотношение } \\
\text { атомов Аu (III) и } \\
\text { числа звеньев } \\
\text { полимера при } \\
\text { синтезе, } \\
\text { моль : моль }\end{array}$} & \multirow{2}{*}{$\begin{array}{c}\text { Максимальная } \\
\text { концентрация } \\
\text { раствора } \\
\text { аурумакрила по } \\
\text { общим сухим } \\
\text { веществам, } \\
\text { мг/мл }\end{array}$} & \multirow{2}{*}{$\begin{array}{c}\mathrm{A}_{226.5} \\
\text { концентри- } \\
\text { рованного } \\
\text { раствора } \\
\text { аурумакрила, } \\
\text { Ед./мл }\end{array}$} & \multirow{2}{*}{$\begin{array}{c}\text { Содержание } \\
\text { ионного Au, } \\
\text { мкмоль/ } \\
\text { мг сухого } \\
\text { вещества }\end{array}$} & \multicolumn{2}{|c|}{$\begin{array}{l}\text { Доля выживших клеток } \\
\text { МСF-7 по результатам } \\
\text { MTT-теста при концентрации } \\
\text { аурумакрила } \mathrm{A}_{226,5} \text { в мл }\end{array}$} \\
\hline & & & & & & & & 9,1 мЕД. & 91,0 мЕд. \\
\hline 1 & 5,7 & $100-300$ & $\mathrm{H}$ & $1: 32$ & 2,7 & 0,91 & 12,5 & 5 & 49 \\
\hline 2 & 3,0 & 1,6 & $\mathrm{H}$ & $1: 10$ & 29,4 & 2,40 & 32,8 & 5 & 51 \\
\hline 3 & 3,0 & 1,6 & $\mathrm{H}$ & $1: 10$ & 28,3 & 3,00 & 41,0 & 5 & 47 \\
\hline 4 & 3,0 & 11,5 & $\mathrm{H}$ & $1: 10$ & 29,4 & 1,00 & 15,5 & 5 & 21 \\
\hline 5 & 3,0 & 100 & $\mathrm{H}$ & $1: 10$ & 29,4 & 1,53 & 21,0 & 4 & 45 \\
\hline 6 & 3,0 & 100 & $\mathrm{H}$ & $1: 10$ & 33,3 & 3,00 & 41,0 & 5 & 46 \\
\hline 7 & 3,0 & 140 & $\mathrm{H}$ & $1: 5$ & 29,4 & 4,80 & 65,5 & 5 & 42 \\
\hline 8 & 3,0 & 140 & $\mathrm{H}$ & $1: 10$ & 29,4 & 2,00 & 23,6 & 4 & 51 \\
\hline 9 & 3,0 & 140 & $\mathrm{H}$ & $1: 10$ & 47,0 & 4,30 & 58,7 & 5 & 44 \\
\hline 10 & 3,0 & 250 & $\mathrm{H}$ & $1: 10$ & 29,4 & 2,00 & 24,2 & 4 & 60 \\
\hline 11 & 3,0 & 250 & $\mathrm{H}$ & $1: 10$ & 16,7 & 0,96 & 13,2 & 5 & 54 \\
\hline 12 & 0,1 & 250 & $\mathrm{H}$ & $1: 10$ & 4,2 & 0,77 & 10,5 & 6 & 43 \\
\hline 13 & 3,0 & 1000 & $\mathrm{H}$ & $1: 10$ & 29,4 & 0,56 & 7,7 & 5 & 44 \\
\hline 14 & 0,1 & 1000 & $\mathrm{H}$ & $1: 10$ & 5,0 & 0,69 & 9,4 & 6 & 49 \\
\hline 15 & 3,0 & 1,6 & $\mathrm{Na}$ & $1: 10$ & 29,4 & 1,27 & 17,4 & 5 & 45 \\
\hline 16 & 0,1 & 1,6 & $\mathrm{Na}$ & $1: 10$ & 27,3 & 0,39 & 5,4 & 6 & 41 \\
\hline 17 & 3,0 & 5,75 & $\mathrm{Na}$ & $1: 10$ & 29,4 & 1,00 & 14,8 & 6 & 39 \\
\hline 18 & 3,0 & 100 & $\mathrm{Na}$ & $1: 10$ & 29,4 & 1,00 & 18,4 & 4 & 39 \\
\hline 19 & 0,1 & 100 & $\mathrm{Na}$ & $1: 5$ & 12,6 & 2,58 & 35,3 & 6 & 46 \\
\hline 20 & 3,0 & 140 & $\mathrm{Na}$ & $1: 10$ & 29,4 & 1,33 & 18,2 & 11 & 42 \\
\hline 21 & 3,0 & 250 & $\mathrm{Na}$ & $1: 10$ & 29,4 & 1,30 & 17,8 & 6 & 44 \\
\hline 22 & 0,1 & 250 & $\mathrm{Na}$ & $1: 10$ & 13,3 & 0,37 & 5,2 & 7 & 41 \\
\hline 23 & 3,0 & 1000 & $\mathrm{Na}$ & $1: 10$ & 29,4 & 0,37 & 5,2 & 11 & 49 \\
\hline 24 & 0,1 & 1000 & $\mathrm{Na}$ & $1: 10$ & 10,0 & 0,54 & 7,5 & 9 & 38 \\
\hline
\end{tabular}

Примечание. Серым выделены образцы, подвергшиеся лиосильной сушке с последующим растворением в воде, без выделения - образцы, не подвергавшиеся сушке и хранившиеся в виде раствора.

Таблица 2. Распределение размеров наночастиц золота в образцах аурумакрила, полученных из ПАК и ПА-Na

\begin{tabular}{|c|c|c|c|c|c|c|c|}
\hline \multirow{2}{*}{ Mr полимера, кДа } & \multirow{2}{*}{ Противо-ион } & \multirow{2}{*}{$\begin{array}{c}\text { Соотношение числа атомов Аu (III) и } \\
\text { звеньев полимера при синтезе, моль : моль }\end{array}$} & \multicolumn{5}{|c|}{ Содержание частиц с указанным диапазоном среднего размера, \% } \\
\hline & & & $1-10$ нм & $11-20$ нм & 20-50 нм & 50-100 нм & $>100$ нм \\
\hline 1,6 & $\mathrm{H}$ & $1: 5$ & 76,0 & 14,0 & 10,0 & 0,0 & 0,0 \\
\hline 1,6 & $\mathrm{H}$ & $1: 10$ & 57,5 & 25,0 & 15,0 & 2,5 & 0,0 \\
\hline 11,5 & $\mathrm{H}$ & $1: 10$ & 84,0 & 12,0 & 4,0 & 0,0 & 0,0 \\
\hline 250 & $\mathrm{H}$ & $1: 10$ & 42,9 & 48,6 & 8,6 & 2,9 & 0,0 \\
\hline 1000 & $\mathrm{H}$ & $1: 10$ & 36,0 & 50,0 & 2,0 & 0,0 & 12,0 \\
\hline 11,5 & $\mathrm{Na}$ & $1: 5$ & 82,0 & 8,0 & 6,0 & 4,0 & 0,0 \\
\hline 140 & $\mathrm{Na}$ & $1: 5$ & 78,0 & 16,0 & 6,0 & 0,0 & 0,0 \\
\hline 140 & $\mathrm{Na}$ & $1: 10$ & 0,0 & 2,5 & 0,0 & 22,5 & 75,0 \\
\hline $100-300$ & $\mathrm{H}$ & $1: 0,0018$ & 46,7 & 23,3 & 30,0 & 0,0 & 0,0 \\
\hline
\end{tabular}


наночастицы не обнаружены. Для контрольного образца аурумакрила, синтезированного по ранее описанному способу, характерно необычно высокое процентное содержание наночастиц золота со средним диаметром 20-50 нм, в несколько раз превышающее содержание подобных наночастиц в образцах, синтезированных в рамках настоящей работы.

Для окончательного подтверждения гипотезы о том, что цитотоксическая активность образцов аурумакрила пропорциональна содержанию в них Au в ионной форме и не зависит от содержания полиакрилата, металлического золота и других компонентов, наиболее активные образцы № 3, 10 и 17 (см. табл. 1) подвергали более детальному исследованию цитотоксической активности в отношении клеточной линии MCF-7. Для этого исходные растворы образцов приводили к одинаковой концентрации золота в ионной форме, используя в качестве критерия величину поглощения при $\lambda=226,5$ нм в 100 мM HCl. В качестве положительного контроля использовали образец аурумакрила, синтезированный по ранее описанному способу. Результаты теста представлены на рис. 1.

Значения зависимости цитотоксической активности от содержания Au (III) для образцов №3, № 10 и контрольного образца полностью совпадают, несмотря на то, что все образцы существенно различаются по составу и способу получения. Так, образец № 3 получили из ПАК со средней массой молекулы 1,6 кДа (низкая степень полимеризации) и подвергали лиофилизации. Образец № 10 получили из ПАК массой 250 кДа и после синтеза хранили в форме раствора. Контрольный образец получили при соотношении золота и звена полимера, равном 1: 32 против 1: 10 в случае препаратов № 3 и № 10. В результате образцы в несколько раз различаются по растворимости и соотношению Au (III) и ПАК. Данные табл. 2 позволяют предполагать, что они существенно отличаются друг от друга и по содержанию металлического золота в форме наночастиц. Тем не менее, выровняв концентрации растворов этих трех образцов по содержанию Au (III), мы получили образцы с неотличимой друг от друга цитотоксической активностью в отношении клеток молочной железы MCF-7.

$\%$

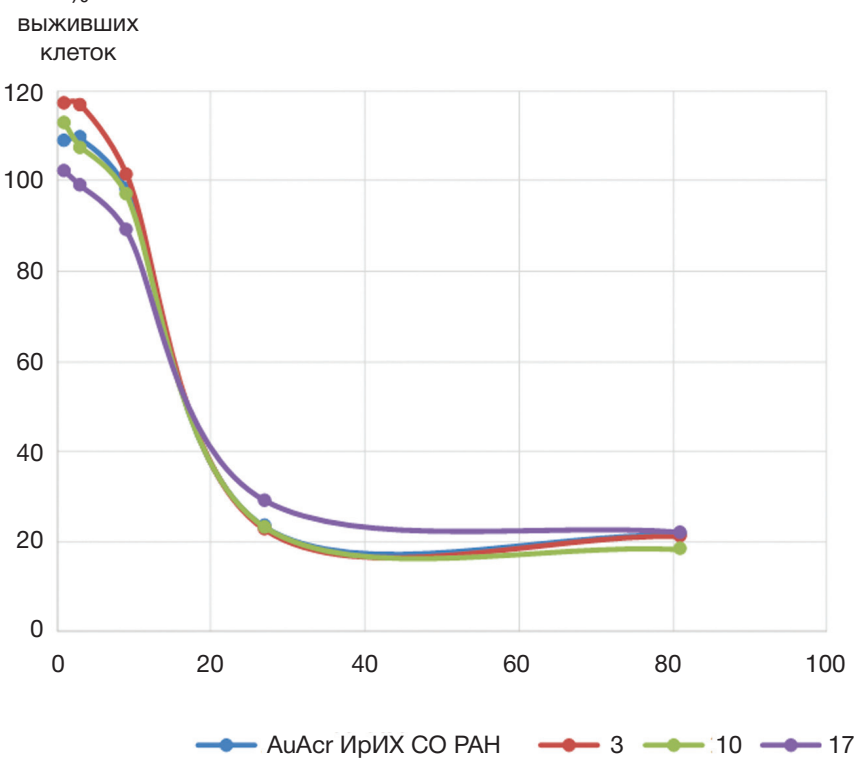

Зависимость цитотоксической активности образца № 17, полученного при использовании в качестве исходного полимера ПА-Na средней молекулярной массой 5,75 кДа без использования лиофилизации, показывает наличие у него некоторых качественных отличий от других тестируемых образцов. При низкой концентрации в растворе (0-10 мЕд./Мл) Он показывает более высокую цитотоксическую активность, чем образцы, полученные при использовании ПАК, а при высоких концентрациях 25 и 90 мЕд./мл уступает им в удельной цитотоксической активности. Это наблюдение показывает, что в результате реакции золотохлороводородистой кислоты с ПАК и ПА-Na происходит образование образцов с несколько различающейся биологической активностью ионов Au.

В заключении необходимо отметить, что практическое использование образцов аурумакрила, полученных с применением в качестве исходного материала ПА-Na (В отличие от ПАК), затруднено из-за их недостаточной стабильности при хранении. Как растворы, так и лиофилизованно высушенные образцы этого типа вне зависимости от молекулярной массы полимера склонны К спонтанному восстановлению содержащихся в них ионов Аи с образованием металлических наночастиц, что ведет к быстрому падению их цитотоксической активности.

\section{ОБСУЖДЕНИЕ}

В работе [3] представлены результаты исследования противоопухолевой активности аурумакрила in vivo $и$ in vitro. Утверждается, что при однократном внутрибрюшинном введении в дозировке 20 мг на 1 кг массы образец тормозит развитие солидных опухолей мышей: карциномы легких Льюис, аденокарциномы Акатол и аденокарциномы Са-755 на 80-90\% по сравнению с контролем. В экспериментах in vitro в концентрации 1 мг/мл образец вызывает гибель 70\% клеток карциномы молочной железы человека MCF-7. Сообщается, что гибель клеток карциномы молочной железы человека MCF-7 под влиянием аурумакрила происходит как в результате некроза, так и вследствие индукции апоптоза [3]. Механизм избирательного 
противоопухолевого действия аурумакрила in vivo остается невыясненным, однако при внутрибрюшинном введении не наблюдается избирательной аккумуляции атомов золота в опухоли, а происходит равномерное их распределение по организму экспериментального животного при достаточно быстром выведении с экскретами [3].

За последние три года появился целый ряд сообщений о том, что полимеры акриловой кислоты способны эффеккиивно доставлять в опухолевые клетки in vitro $и$ in vivo различные агенты, обладающие цитотоксическим или антипролиферативным эффектом (см. ниже). При этом имеется в виду способность полиакриловых частиц различной массы как избирательно доставлять вещества в опухолевые клетки, так и усиливать активность противоопухолевых агентов внутри клеток. Акцентируется также внимание на способности полиакрилатов избирательно накапливаться в дендритных клетках и макроффагах, что может влиять на эффективность презентации лимфоидным клеткам антигенов, связанных с полиакрилатными носителями. Так, сообщается о положительном результате испытаний конъюгата полиакрилата с пептидами-антигеномиметиками онкопротеина E7 папиломавируса 16 (HPV16) [4]. Частицы полиакрилата, иммобилизованные внутри вирусоподобных частиц HBsантигена вируса гепатита В, усиливали цитотоксическую активность доксорубицина [5]. Имеются данные об эффективном подавлении роста клеток карциномы легких A495 за счет доставки в них пероксованадата [6]. В другой работе сообщается о возможности использования сополимера полиакрилата с фосфатом кальция для доставки наноразмерных кластеров золота как для терапии солидных опухолей, так и для их констатирования (принцип тераностики) [7].

Разнообразны способы применения полиакриловых кластеров для доставки наночастиц оксида титана, ферромагнетиков, солей и оксидов других металлов с целью создания радиосенсибилизаторов, достижения цитотоксического эффекта или средств биоимиджинга на принципах флуоресценции или магнитного резонанса [8-11]. Полиакрилат был успешно применен для доставки метиленового синего в клетки карциномы молочной железы MCF-7, который выступал в роли фотосенсибилизатора для фотодинамической терапии [12]. Все приведенные данные косвенно указывают на наличие некоторой избирательности связывания полиакрилатов с опухолевыми клетками in vivo. Механизм этого действия практически не обсуждается, однако имеющиеся данные не позволяют предположить, что ПАК сама по себе оказывает цитотоксическое действие на опухолевые клетки. Эта функция, наиболее вероятно, лежит на ионе $\mathrm{Au}$ (III), доставляемого в клетки с помощью ПАК.

Этот тезис можно проиллюстрировать данными работы [13], где описаны соединения Au (III): дихлоридо(этилендиамин) аурат и дихлоридо(S-метил-І-цистеин)аурат, обладающие выраженной цитотоксичностью в отношении клеток лимфолейкемии человека. Авторы доказали, что подобно производному платины - цисплатину, ионы Au (III) из состава указанных соединений могут образовывать аддукты с ДНК в живых клетках, что и приводит к их гибели.

Выполнение биологических испытаний безопасности и специфической фрармакологической (противоопухолевой) активности, а тем более практическое применение аурумакрила, синтезируемого согласно ранее описанному способу [1], затруднено его недостаточной растворимостью. При введении животным (мышам) аурумакрила в эсффективной дозировке 20 мг на 1 кг живой массы необходимо использование раствора с концентрацией основного вещества 1 мг/мл [3]. С учетом того что масса мыши около 20 г, это требует одновременного введения каждому животному 200 мкл образца, что приближается к предельно допустимому объему вводимого вещества: дальнейшее увеличение объема снизит выживаемость экспериментальных животных вне зависимости от состава испытуемого образца. Хранение сухих образцов в течение 6 месяцев при температуре $+4{ }^{\circ} \mathrm{C}$ приводило к дальнейшему существенному снижению их растворимости.

Выполненное в рамках настоящей работы варьирование свойств полиакрилатного полимера и его соотношения с золотохлористоводородной кислотой в процессе синтеза впервые позволило исследовать влияние этих факторов на выход реакции. Сопоставление цитотоксической активности полученных образцов аурумакрила с существенно различающимся соотношением ионов золота и полиакрилатного полимера позволило установить, что удельное содержание в образце ПАК и его молекулярная масса практически не сказываются на биологических свойствах образца. Напротив, содержание ионов Au (III), определяемое по поглощению растворов аурумакрила при $\lambda=226,5$ нм, позволяет с высокой точностью предсказать их цитотоксическую активность на клеточной культуре in vitro.

Однако соотношение концентраций полиакрилатного полимера и тетрахлораурат-иона, молекулярная масса полимера и абсолютная концентрация раствора полимера существенно сказываются на выходе золота в ионной форме в готовом образце, а также на растворимости образца. Так, использование полимера со степенями полимеризации 1389 и 1944 позволяет добиться максимальной растворимости продукта - неполной золотой соли. Использование более высокомолекулярных полимеров приводит к снижению растворимости продукта: небольшому для полимера со степенью полимеризации 3472 и драматическому при использовании полимера со степенью полимеризации 13 889. При использовании низкомолекулярных полимеров со степенью полимеризации 23, 80 и 160 в некоторых случаях возможно получение продукта с высокой растворимостью и хорошим выходом, однако воспроизводимость методики синтеза в таком случае оказывается неудовлетворительной ввиду повышенной склонности этих композитов к образованию наночастиц. Полимер со степенью полимеризации 1389 несколько уступал по свойствам полимеру со степенью полимеризации 1944.

Соотношение золотохлористоводородной кислоты и звена полимера, равное 1 : 5, в случае полимера со средней массой 140 кДа обеспечивало несколько более высокий выход растворимого продукта по сравнению с соотношением 1 : 10. Было установлено, что использование в реакции концентрированного раствора полиакрилатного полимера (3\%) существенно повышает выход золота в ионной форме по сравнению с разбавленным раствором (0,1\%). Наличие $\mathrm{Na}^{+}$в качестве противоиона карбоксильных групп полиакрилатного полимера приводило к снижению выхода ионного золота примерно на 10\%. Кроме того, наличие в образце ионов $\mathrm{Na}^{+}$снижало сохранность образцов аурумакрила при хранении. Находясь при температуре $+4{ }^{\circ} \mathrm{C}$ в течение 5-30 суток, такие образцы вне зависимости от массы полимера показывали признаки неуклонного спонтанного восстановления ионов Аu (III) до металлических наночастиц. Таким образом, предварительная деионизация полимера 
с целью удаления катионов щелочных металлов является необходимым условием пригодности полиакрилатного полимера для синтеза аурумакрила.

Существенным результатом работы является вывод о том, что при контакте тетрахлораурат-иона даже с очищенным полиакрилатным полимером возможно восстановление атома золота до металла с образованием золотых наночастиц. Именно эта реакция приводит к снижению выхода действующего вещества при синтезе аурумакрила. Данное наблюдение было сделано благодаря использованию метода трансмиссионной электронной микроскопии, позволяющего наблюдать электронно-непрозрачные наночастицы, прочно связанные с полимером. Показано, что присутствие в образцах аурумакрила наночастиц золота, имеющих диаметр 1-100 нм, в исследованном диапазоне концентраций не сказывается на цитотоксической активности образцов в отношении клеток MCF-7, а является лишь косвенным свидетельством снижения содержания золота в биологически активной ионной форме.

Благодаря сопоставлению содержания золота в ионной форме по поглощению при 226,5 нм и цитотоксической активности образцов аурумакрила была разработана методика оценки качества образца по содержанию действующего вещества. Было показано, что вне зависимости от способа синтеза и молярного соотношения ионов Au и полиакрилатного полимера цитотоксическая активность раствора аурумакрила в отношении перевиваемой клеточной линии MCF-7 пропорциональна его $A_{226,5}$. Таким образом, контроль качества аурумакрила должен, в первую очередь, включать определение поглощения насыщенного раствора в УФ области при $\lambda=226,5$ нм. Во избежание влияния гидролиза на результаты измерения анализ необходимо проводить в кислой среде (например, в 100 мМ соляной кислоте). Благодаря использованию этого принципа удалось оценить выход процедуры синтеза и провести оптимизацию условий проведения реакции полиакрилатного полимера с золотохлористоводородной кислотой.

Тот факт, что определение содержания золота в ионной форме позволяет предсказывать токсичность раствора аурумакрила для клеток MCF-7 вне зависимости от концентрации в нем полиакрилатного полимера, позволяет сделать вывод о том, что роль полиакрилатного полимера в транспортировке ионов золота в клетки не является ключевой или, во всяком случае, не лимитирует эсффективность проникновения золота в клетки in vitro. Однако нельзя исключать, что в экспериментах in vivo значение полиакрилатного полимера в адресации ионов золота в опухоль может оказаться более важным. Для исследования свойств полиакрилатного полимера в качестве носителя в биологических системах необходимо исследовать цитотоксичность имеющихся образцов аурумакрила в отношении других опухолевых линий и первичных клеточных культур in vitro. Необходимо также сравнить их неспецифическую токсичность и противоопухолевую активность in vivo.

В отличие от ранее описанного в литературе способа, по окончании синтеза продукт подвергали высушиванию не на воздухе или в вакуум-эксикаторе, а с помощью лиофильной сушки. Такое высушивание существенно улучшило растворимость аурумакрила в физиологических условиях, доведя ее в среднем до 30 мг/мл по содержанию сухих веществ, а также позволило добиться стабильности препарата при хранении.

В результате предложенных усовершенствований способа синтеза аурумакрила удалось добиться возможности получать раствор с $A_{226,5}=4,8$ (в пересчете на длину оптического пути, равного 1 см), что в 5,3 раза превышает наилучший результат для образцов аурумакрила, полученных по ранее описанному способу $\left(A_{226,5}=0,9\right)$. Цитотоксическая активность такого раствора возрастает пропорционально $A_{226,5}$. Использование более концентрированных растворов существенно облегчит проведение испытаний биологической активности in vivo и in vitro, а в перспективе и практическое применение образца в противоопухолевой терапии.

В заключение необходимо отметить, что применение аурумакрила в медицине нецелесообразно ограничивать только адъювантной химиотерапией карцином. Полученные в настоящей работе данные ТЭМ показывают, что при контакте с восстановителями аурумакрил способен образовывать наночастицы золота. С учетом большого атомного радиуса золота такие частицы могут служить радиосенсибилизатором, позволяющим усиливать действие ионизирующего излучения на клетки [14]. Эффективности такого подхода может способствовать выявленная в настоящей и предшествующей работах [3] тропность аурумакрила к опухолевым клеткам, что позволяет ожидать предпочтительного накопления наночастиц золота в опухолевых клетках по сравнению с нормальными тканями.

\section{ВЫВОДЫ}

Сопоставление цитотоксической активности полученных образцов аурумакрила с существенно различающимся соотношением ионов золота и полиакрилатного полимера позволило установить, что удельное содержание в образце полиакрилатного полимера и его молекулярная масса практически не сказываются на биологических свойствах конечного продукта. Напротив, измерение содержания ионов Au (III) по поглощению растворов аурумакрила при $\lambda=226,5$ нм позволяет с высокой точностью предсказать их цитотоксическую активность на клеточной культуре MCF-7 in vitro. Для получения препарата аурумакрил с максимальным выходом Au (III) и наилучшей растворимостью в воде необходимо использовать тщательно деионизованную свободную ПАК со средней молекулярной массой 140 кДа, вводить ее в синтез в концентрации 3\% при молярном соотношении золотохлористоводородной кислоты и звена полимера, равного 1 : 5, а после окончания синтеза подвергать раствор лиофильному высушиванию.

Полученные данные могут быть полезны при составлении плана реализации и проведения доклинических испытаний аурумакрила. 


\section{Литература}

1. Абзаева К. А., Белозерская Г. Г., Малыхина Л. С., Жилицкая Л. В. Федорин А. Ю., Бычичко Д. Ю. и др. Неполная золотая соль полиакриловой кислоты, способ ее получения и средство на ее основе, обладающее гемостатическим действием при наружном применении. Патент РФ № 2607 519. Приоритет 25.11.2015. Опубликовано: 10.01.2017, Бюл. № 1.

2. Макотченко Е. В., Малкова В. И., Белеванцев В. И. Электронные спектры поглощения галогенидных комплексов золота (III) в водных растворах. Координационная химия. 1999; 25 (4): 302-9.

3. Островская Л. А., Корман Д. Б., Грехова А. К., Блюхтерова Н. В., Фомина М. М., Рыкова В. А., и др. Экспериментальное изучение противоопухолевой активности полиакрилата золота. Российский биотерапевтический журнал. 2018; 17 (5): 54-5.

4. Liu TY, Hussein WM, Giddam AK, et al. Polyacrilic-based delivery system for self-adjuvanting anticancer peptide vaccine. J Med Chem. 2015; (58): 886-96.

5. Biabanikhankahdani R, Alitheen NB, Ho KL, Tan WS. pHresponsive Virus-like Nanoparticles with Enhanced Tumourtargeting Ligands for Cancer Drug Delivery. Sci Rep. 2016; 24 (6): 37891

6. Chatterill N, Anwar T, Islam NS, et al. Growth arrests of lung carcinoma cells (A549) by polyacryl-anchored peroxovanadat by activating Rac1-NADPH oxidase signaling axis. Mol Cell Biochem. 2016; (420): 9-20.

7. $\mathrm{Li} \mathrm{H}, \mathrm{Hu}$ J, Wu S, et al. Auranofin-mediated inhibition of PI3K/AKT/ mTOR axis and anticancer activity in non-small cell lung cancer cells. Oncotarget. 2016; (7): 3548-58.

\section{References}

1. Abzaeva KA, Belozerskaya GG, Malykhina LS, Zhilitskaya LV, Fedorin AYu, Bychichko DYu, et al. Incomplete golden salt of polyacrylic acid, method of its manufacturing and a medicine derived thereof exhibiting a hemostatic action up on external application. Patent RU \# 2607 519. Priority since Nov. 25. 2015. Published: Jan. 10. 2017, Bull. \# 1.

2. Makotchenko EV, Malkova VI, Belevantsev VI. Electronic absorption spectra of the gold (III) halide complexes in aqueous solutions. Rus J Coord Chem. 1999; 25 (4): 282-289.

3. Ostrovskaja LA, Korman DB, Grehova AK, Bljuhterova NV, Fomina MM, Rykova VA i dr. Jeksperimental'noe izuchenie protivoopuholevoj aktivnosti poliakrilata zolota. Rossijskij bioterapevticheskij zhurnal. 2018; 17 (5): 54-5.

4. Liu TY, Hussein WM, Giddam AK, et al. Polyacrilic-based delivery system for self-adjuvanting anticancer peptide vaccine. J Med Chem. 2015; (58): 886-96.

5. Biabanikhankahdani R, Alitheen NB, Ho KL, Tan WS. pHresponsive Virus-like Nanoparticles with Enhanced Tumourtargeting Ligands for Cancer Drug Delivery. Sci Rep. 2016; 24 (6): 37891.

6. Chatterill N, Anwar T, Islam NS, et al. Growth arrests of lung carcinoma cells (A549) by polyacryl-anchored peroxovanadat by activating Rac1-NADPH oxidase signaling axis. Mol Cell Biochem. 2016; (420): 9-20.

7. $\mathrm{Li} \mathrm{H}, \mathrm{Hu} \mathrm{J}, \mathrm{Wu}$ S, et al. Auranofin-mediated inhibition of PI3K/AKT/ mTOR axis and anticancer activity in non-small cell lung cancer cells. Oncotarget. 2016; (7): 3548-58.
8. Morita J, Kano K, Kato K, Takita H, Sakagami H, Yamamoto Y, et al. Structure and biological function of ENPP6, a choline-specific glycerophosphodiester-phosphodiesterase. Sci Rep. 2016; (6): 20995.

9. Nakayama M, Sasaki R, Ogino C, Tanaka T, Morita K, Umetsu M, et al. Titanium peroxide nanoparticles enhanced cytotoxic effects of X-ray irradiation against pancreatic cancer model through reactive oxygen species generation in vitro and in vivo. Radiat Oncol. 2016; 11 (1): 91

10. Lungu II, Rădulescu M, Mogoșanu GD, Grumezescu AM. pH sensitive core-shell magnetic nanoparticles for targeted drug delivery in cancer therapy. Rom J Morphol Embryol. 2016; 57 (1): 23-32.

11. Xu Y, Sherwood JA, Lackey KH, Qin Y, Bao Y. The responses of immune cells to iron oxide nanoparticles. J Appl Toxicol. 2016; 36 (4): 543-53.

12. Khanal A, Bui MP, Seo SS. Microgel-encapsulated methylene blue for the treatment of breast cancer cells by photodynamic therapy. J Breast Cancer. 2014; 17 (1): 18-24.

13. Milovanović $M$, Djeković A, Volarević $\mathrm{V}$, Petrović $\mathrm{B}$, Arsenijević $\mathrm{N}$, Bugarcić ZD. Ligand substitution reactions and cytotoxic properties of $[\mathrm{Au}(\mathrm{L}) \mathrm{Cl} 2]+$ and $[\mathrm{AuCl} 2(\mathrm{DMSO}) 2]+$ complexes (L-ethylenediamine and S-methyl-I-cysteine). J Inorg Biochem. 2010; 104 (9): 944-9.

14. Peukert D, Kempson I, Douglass M, Bezak E. Metallic nanoparticle radiosensitisation of ion radiotherapy: A review. Phys Med. 2018; (47): $121-8$

8. Morita J, Kano K, Kato K, Takita H, Sakagami H, Yamamoto Y, et al. Structure and biological function of ENPP6, a choline-specific glycerophosphodiester-phosphodiesterase. Sci Rep. 2016; (6): 20995.

9. Nakayama M, Sasaki R, Ogino C, Tanaka T, Morita K, Umetsu M, et al. Titanium peroxide nanoparticles enhanced cytotoxic effects of X-ray irradiation against pancreatic cancer model through reactive oxygen species generation in vitro and in vivo. Radiat Oncol. 2016; 11 (1): 91.

10. Lungu II, Rădulescu M, Mogoşanu GD, Grumezescu AM. pH sensitive core-shell magnetic nanoparticles for targeted drug delivery in cancer therapy. Rom J Morphol Embryol. 2016; 57 (1): 23-32.

11. Xu Y, Sherwood JA, Lackey KH, Qin Y, Bao Y. The responses of immune cells to iron oxide nanoparticles. J Appl Toxicol. 2016; 36 (4): 543-53.

12. Khanal A, Bui MP, Seo SS. Microgel-encapsulated methylene blue for the treatment of breast cancer cells by photodynamic therapy. J Breast Cancer. 2014; 17 (1): 18-24.

13. Milovanović $\mathrm{M}$, Djeković A, Volarević $\mathrm{V}$, Petrović $\mathrm{B}$, Arsenijević $\mathrm{N}$, Bugarcić ZD. Ligand substitution reactions and cytotoxic properties of $[\mathrm{Au}(\mathrm{L}) \mathrm{Cl} 2]+$ and $[\mathrm{AuCl} 2(\mathrm{DMSO}) 2]+$ complexes (L-ethylenediamine and S-methyl-I-cysteine). J Inorg Biochem. 2010; 104 (9): 944-9.

14. Peukert D, Kempson I, Douglass M, Bezak E. Metallic nanoparticle radiosensitisation of ion radiotherapy: A review. Phys Med. 2018; (47): 121-8. 